\title{
Effect of Financial Crisis on Firm Performance in Malaysia
}

Caleb Cheng Ee Wan, Joanne Shaza Janang, Sin Kit-Yeng, Nur Nadhira Binti Baharuddin

To Link this Article: http://dx.doi.org/10.6007/IJARBSS/v11-i9/10593

DOI:10.6007/IJARBSS/v11-i9/10593

Received: 02 July 2021, Revised: 12 August 2021, Accepted: 30 August 2021

Published Online: 27 September 2021

In-Text Citation: (Wan et al., 2021)

To Cite this Article: Wan, C. C. E., Janang, J. S., Kit-Yeng, S., \& Baharuddin, N. N. B. (2021). Effect of Financial Crisis on Firm Performance in Malaysia. International Journal of Academic Research in Business and Social Sciences, 11(9), 1725-1734.

Copyright: (c) 2021 The Author(s)

Published by Human Resource Management Academic Research Society (www.hrmars.com)

This article is published under the Creative Commons Attribution (CC BY 4.0) license. Anyone may reproduce, distribute, translate and create derivative works of this article (for both commercial and non-commercial purposes), subject to full attribution to the original publication and authors. The full terms of this license may be seen at: http://creativecommons.org/licences/by/4.0/legalcode

Vol. 11, No. 9, 2021, Pg. 1725 - 1734

Full Terms \& Conditions of access and use can be found at http://hrmars.com/index.php/pages/detail/publication-ethics 


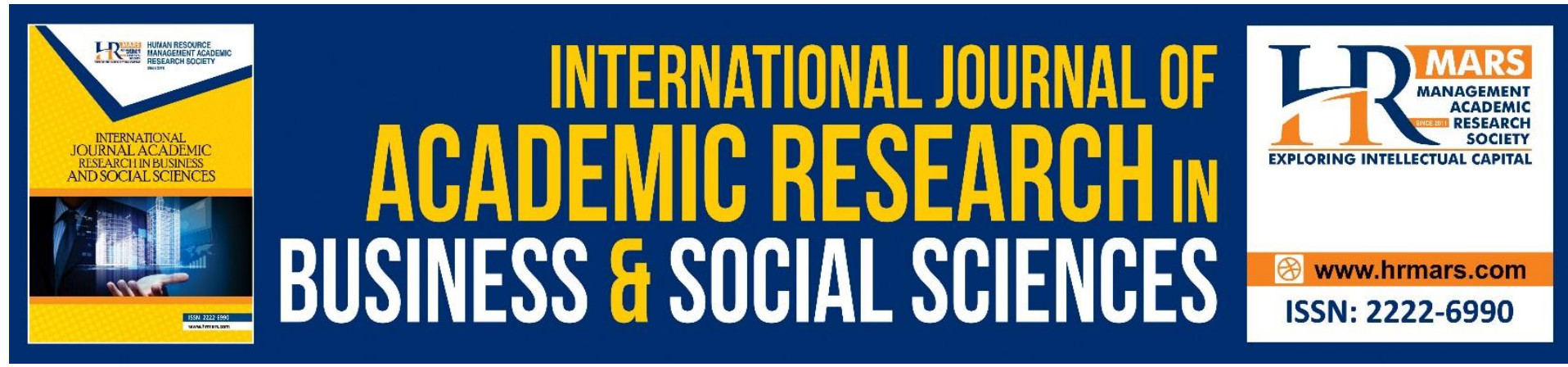

\title{
Effect of Financial Crisis on Firm Performance in Malaysia
}

\section{Caleb Cheng Ee Wan, Joanne Shaza Janang, Sin Kit-Yeng, Nur Nadhira Binti Baharuddin}

University of Malaysia Sarawak, Faculty of Economics and Business, 94300 Kota Samarahan, Sarawak

\begin{abstract}
The purpose of conducting this research is to analyse the relationship between financial crisis and performance of the 14 consumer services listed firms in Bursa Malaysia main market. The period chosen in this research covers from 2015 to 2019, which is 5 years in total. Generally, firms' value that obtained through the ratio of return on total asset (ROA) serves as the dependent variable in this research. Two independent variables involve in this research are debt ratio and debt to equity ratio.
\end{abstract}

Keywords: Firm Performance, Financial Crisis, Consumer Services Listed Firms.

\section{Introduction}

Firstly, according to Kenton (2021), the value of asset decreases rapidly during financial crisis, companies and customers failed to repay their liabilities, and shortages of liquidity are faced by the financial institution. This mean that the debt of the company would increase during financial crisis. Thus, the company may face with the challenges in term of the profitability and leverage as the profit may decrease but increase in leverage. Besides, the researcher also mentioned that the investors of company may withdraw their money and sell their shares to prevent the loss as they noticed that the performance and value of the company may get negative effect during financial crisis. Thus, this study show that debt experienced a significant relationship with firms' value.

In this study, firms that are going to be observed are the consumer services company that reported on the Bursa Malaysia main market. Debt of the firms will be observed and calculated based on the leverage ratio which is debt ratio and debt to equity ratio. According to Hayes (2021), debt ratio act as a financial ratio to measure the company's leverage and is defined as the percentage of a company's debt-funded assets. It is obtained by dividing the total liabilities by total assets of company. Besides, Bloomenthal (2021) stated that debt to equity ratio accounts for the percentage between a corporation's equity to debt used to finance its properties and indicates the degree to which shareholder equity will satisfy its commitments to creditors in the event of a market loss. It can be computed through dividing the total liabilities of the company by the amount of total shareholder equity.

Firm performance will be observed through the calculation of profitable ratio which is return on total asset (ROA). Based on the research of Hargrave (2021), ROA can be act as the 
indicator to measure the profit of a company and how the company can manage its asset efficiently to perform well on its profit. Thus, this ratio is chosen in this study to measure the company value. Value of ROA can be determined by dividing the net sales by the company's total assets. Therefore, this research objective is to examine the effect of leverage on the value of firms.

\section{Literature Review}

Firms' value is the dependent variable in this study and according to Borad (2021), it acts as the indicators for the investors to measure the true value of firms when investing in it. Firms' value is essential for the investors to get the exact value of the firm and observed whether it is undervalued or not. There are several factors that can influence the value of the firms like cash and debt (Tracy, 2021). Besides, Hidayah (2014) studied that the firms with high value can increase the confidence of the investors to invest in the firms as they can get more benefits from firms. According to Hannagan (2008), ROA aims to tell us how well the firms are generating profits based on its assets. This is one of the famous ways of comparing firms to each other. In the research of Hargrave (2021), debt of the company is included in the calculation of ROA when determine the value of companies. Mcclure (2021) studied that it is better for the firms have a high ROA as it implies the firms can manage well in converting its investments into profits.

As one of the independent variables, debt ratio is obtained through dividing the total debt of a firm by its total assets. The ratio calculates the quantity of leverage used by the firm in terms of total debts to total assets. According to Hayes (2021), when the amount of debt ratio is greater than 1, it implies that the firms have more debt than assets. In the other hand, if the amount of debt ratio is less than 1, it indicates that the firms have higher amount of assets than debt. Based on the findings of Ross (2021), debt ratio is one of the essential measurement or indicators to define the performance and financial health of the firms. According to the research by Shubiri (2012), he studied the effect of debt ratio to the investment activities of firms in Jordan and found out that there is no negative effect of total debt ratio to the investment activities provided in the firms. Bragg (2021) pointed that a firm will experience in high risk of financing when the debt of the company is high.

According to Fernando (2021), debt-to-equity ratio aims to identify the amount of leverage a firm is using and computed by dividing total debt of company by total shareholder's equity. The higher the ratio, the higher the risk and will bring negative effect to the firm. As stated by Grunert (2021), debt-to-equity ratio is important for the firms to identify their value and finance their operational activities that affect to the long-term growth. Basically, lenders will prefer a low debt-to-equity ratio of firms as the interests of firms are better protected during financial crisis. On the other hand, Ali (2020) pointed out that debt-to-equity ratio is important for the firms to measure as it will affect the performance of the companies as well as the financial risk. Moreover, capital structure also acts as the fundamental indicator in the financial management of the firms. Based on the explanations above, the hypothesis is developed as follows:

\section{$H_{1}$ : There is significant relationship between debt ratio and ROA. $\mathrm{H}_{2}$ : There is significant relationship between debt-to-equity ratio and ROA.}

Breuer and Gurtler (2008) studied that there are three essential version of M\&M theorem that can be drawn. First, value of firms is independent to capital structure of firms. 
Second, cost of equity is directly proportional to the debt-equity ratio and the next version is the dividend policy of firms is independent to its value.

During financial crisis, the debt or leverage of the company may increase to a certain limitation and this may affect the firms' value. First version of Modigliani-Miller theorem mentioned about the firms' value is independent to the capital structure and firms' value can be calculated based on the present value of its future earnings (Chen, 2020). Based on the findings of Tuovila (2021), capital structure can define as the amount of liability and equity issued by a firm to finance its activities or operations. Thus, M\&M stated that the amount of the debt in a firm will not affect its value.

Chen (2004) studied that static trade-off theory shows a positive relationship between profit and firms' leverage. This mean that increase in leverage of the firms will result in the increase of the firms' profit. When the profit of the firms' increases, it may attract more investor to invest and this can prevent the firms from facing financial problems and reduce the bankruptcy risk. Besides, firms will have better performance as well as increase its value.

According to the research by Chen (2004), pecking order theory shows a negative relationship between leverage and profitability. This mean that when company rely too much on debt or equity financing, it will affect the firms face with low profit as the debt is high. When the profit of the firms decreases, it will decrease the value of firms. Firms will experience a negative effect when it finances through equity funding as the company assumes that the stock price is overvalued and result in the drop of share price.

\section{Research Methodology}

The model used to examine the relationship between financial crisis and firm performance is write as below:

$$
R O A=\beta_{0}+\beta_{1} D R+\beta_{2} D E+\varepsilon
$$

Where:

ROA = Firms value (Return on Total Asset)

$D R=$ Debt ratio

$D E=$ Debt-to-equity ratio

$\beta_{0} \beta_{1} \beta_{2}=$ Coefficients of independent variables

$\varepsilon=$ Error Term

This study covers 14 consumer services firms listed in Bursa Malaysia main market. Firm value act as the dependent variable and it is determined by calculating the return on total asset ratio (ROA). ROA is generated by dividing the net income of the firm by its total assets. On the other hand, independent variable, debt ratio is calculated by dividing the total debt by total assets of the firms while debt to equity ratio is obtained by dividing total liabilities over total shareholders' equity of firms. The data for dependent and independent variables are sourced through the firms' annual report.

Next, descriptive statistics is included in the research and the statistical analysis software, Econometric View (Eviews) is also chosen to calculate the data generated from the firms. It is also used to analyse time series, cross-sectional data and panel data in this research. Besides, Pearson's Correlation Test aims to find out the level of association between independent variables and dependent variable.

Panel data regression is included in this study and it refers to the use of both time series data and cross-sectional data in the study. Breusch \& Pagan Lagrangian Multiplier (LM) Test is generated to determine the more suitable model between Pooled OLD and Random Effect. Hausman Specification Test is used to distinguish whether Random Effect Model or 
Fixed Effect Model is more applicable to use in the research. Besides, Variance Inflation Factor (VIF) is conducted for the multicollinearity test. Breusch - Godfrey (BG) Serial Correlation Test aims to determine the problem of autocorrelation in the model. Jarque - Bera Test is used to evaluate the data obtained in the model is distributed normally or not.

\section{Analysis and Findings}

The result of descriptive analysis is generated as shown below:

\begin{tabular}{|l|c|c|c|}
\hline \multicolumn{1}{|c|}{ Variables } & ROA & DR & DTER \\
\hline Mean & 0.021854 & 0.308455 & 0.698694 \\
\hline Standard deviation & 0.072595 & 0.240183 & 0.870193 \\
\hline Minimum & -0.215286 & 0.017748 & 0.007974 \\
\hline Maximum & 0.188201 & 0.772074 & 3.387389 \\
\hline Observations & 70 & 70 & 70 \\
\hline
\end{tabular}

Note: $\mathrm{ROA}=$ Return on total assets, DR = Debt ratio, DTER = Debt to equity ratio.

The result of Pearson's Correlation Matrix

\begin{tabular}{|l|r|r|r|}
\hline & \multicolumn{1}{|c|}{ ROA } & DR & \multicolumn{1}{c|}{ DTER } \\
\hline ROA & 1.000000 & & \\
\hline DR & 0.023243 & 1.000000 & \\
& $(0.8485)$ & & 1.000000 \\
\hline DTER & -0.011847 & 0.912383 & $(0.0000)$ \\
& $(0.9225)$ & & \\
\hline
\end{tabular}

The result of multicollinearity test (VIF)

\begin{tabular}{|l|c|c|c|}
\hline & Coefficient Variance & Uncentered VIF & Centered VIF \\
\hline DR & 0.008080 & 15.95395 & 5.968099 \\
\hline DTER & 0.000616 & 9.871359 & 5.968099 \\
\hline C & 0.000269 & 3.496759 & NA \\
\hline
\end{tabular}

The result of autocorrelation test

\begin{tabular}{|l|c|}
\hline \multicolumn{2}{|c|}{ BG Serial Correlation Test LM Test } \\
\hline F statistic & 11.81183 \\
\hline Probability & 0.000003 \\
\hline
\end{tabular}

The result of normality test

\begin{tabular}{|l|l|}
\hline \multicolumn{2}{|c|}{ Jarque-Bera Test } \\
\hline F statistic & 4.428610 \\
\hline Probability & 0.109229 \\
\hline
\end{tabular}


The result of panel data regression analysis

\begin{tabular}{|l|c|c|c|}
\hline & Pooled OLS & $\begin{array}{l}\text { Random Effect } \\
\text { Model }\end{array}$ & Fixed Effect Model \\
\hline DR & $\begin{array}{c}0.061423 \\
(0.683322)\end{array}$ & $\begin{array}{c}0.136135 \\
(1.547933)\end{array}$ & $\begin{array}{c}0.193176 \\
(1.924151)\end{array}$ \\
\hline DTER & -0.016456 & -0.018819 & -0.017302 \\
$(-0.663285)$ & $(-0.844185)$ & $(-0.727259)$ \\
\hline C & 0.014405 & -0.006989 & -0.025644 \\
& $(0 / 877971)$ & $(-0.277489)$ & $(-1.117621)$ \\
\hline Breusch \& Pagan & \multicolumn{2}{|c|}{56.56136} & 2 \\
LM Test & \multicolumn{2}{|c|}{$(0.0000)$} & $(0.4109)$ \\
\hline Hausman Test & \multicolumn{3}{|c|}{70} \\
\hline Observations & 70 & & \\
\hline
\end{tabular}

\section{Discussion and Conclusion}

Based on the results of Pearson Correlation, return on total assets (ROA) experienced a positive correlation with debt ratio but a negative relationship with debt-to-equity ratio. Positive correlation showed that both the variables moved in the similar direction while the negative relationship specified the two variables moved in opposite direction. In this study, ROA has a weak and positive correlation with debt ratio. On the other hand, a negative and weak correlation exist between ROA and debt-to-equity.

Besides, the Variance Inflation Factors (VIF) showed that there is no problem of multicollinearity exist in this study as the value is smaller than 10. Nachane (2006) mentioned that the problem exists when the value of VIF is higher than 10 and it means that the independent variables are strongly correlated.

Charles (2021) stated that autocorrelation exists when the computed result is smaller than the p-value $(0.05)$ as the null hypothesis will be rejected and concluded that autocorrelation presents in the study. Based on the result generated above, the $p$-value of BG Test is 0.000003 which is smaller than the significance value and this showed that the model exhibit autocorrelation.

Jarque-Bera Test is chosen to test the normality of the regression model. According to the study by Stephanie (2016), if the computed p-value of the Jarque-Bera Test is larger than the significance value (0.05), null hypothesis will be accepted and concluded that the data is normally distributed. Based on the results above, the computed $p$-value $(0.11)$ is larger than the $5 \%$ significance level $(0.05)$. Thus, the result concluded that the data is normally distributed.

In this study, Pooled OLS is chosen as the null hypothesis while Random Effect model is chosen as the alternative hypothesis for the LM Test. Null hypothesis will be rejected when the computed $p$-value is smaller than $5 \%$ significance level or 0.05 . Based on the result, computed $p$-value in this study is 0.00000 which is smaller than 0.005 . Thus, null hypothesis is rejected and concluded that the Random Effect model is more suitable for the further investigation.

Next, Hausman Specification Test is used to identify the most suitable model from either Random Effect Model or Fixed Effect Model. Random Effect Model is proposed as the 
null hypothesis and we accept null hypothesis when the computed p-value is larger than 0.05 . Based on the results, the computed $p$-value is 0.4109 which is larger than 0.05 . Thus, null hypothesis is accepted and concluded that Random Effect is more suitable than Fixed Effect Model to use in this study.

Furthermore, both the independent variables selected in this study show an insignificant relationship to ROA. In line with the research by Karaca (2012) who examined on the firms in Turkey listed companies with a time period of 8 years and found out that financial debt of a company will not affect significantly to the value. The result from the researcher is matched to the result in this study where there is no significant relationship between ROA and independent variables. Besides, this has also fulfilled the concept of M\&M theory which mentioned that capital structure of firm shows no significant relationship with its value.

In this study, debt ratio acts one of the independent variables and it shows a positive relation with ROA. The result is supported by Lin and Chang (2011) who carried out a study to investigate the effect of different amount of debt ratio to a number of 196 Taiwan listed companies with a time period of 13 years. They have concluded that when the value of debt ratio is below $33 \%$, it shows a positive correlation with the firms' value while the firms' value will continue to increase when the debt ratio is larger than $33 \%$. It means that firms need to have a maximum amount of debt ratio to boost the performance and profit in the firms. Thus, based on the computed result in this study, the mean of the debt ratio is recorded at $30.85 \%$ which is lower than $33 \%$. So, the value of debt ratio in this study experiences a positive relationship with ROA. This means that the study is consistent to the previous research that debt ratio and ROA show a positive relationship with each other.

Besides, debt ratio shows an insignificant relationship with ROA will be chosen as the null hypothesis in this study. Null hypothesis will be accepted when the computed $p$-value is larger than 0.05 or $5 \%$ significance level. So, the computed $p$-value for debt ratio is larger than 0.05 and we accept null hypothesis which stated that debt ratio experiences a positive but insignificant relationship with ROA.

Other than that, the relationship of debt ratio and ROA in this study is consistent with the Static trade-off theory where stated that firms' leverage and firms' value have a positive relationship with each other. The theory mentioned that firms might find easier to apply debt financing rather than equity financing to raise their needed funds. Thus, the lower cost of debt financing can help the firms to increase the value by making more profit with suitable value of debt.

According to the result, debt-to-equity ratio, which is the next independent variable shows a negative relationship with ROA. On the other hand, a research regarding the relationship between capital structure and the performance of listed non-financial firms in Bangladesh with a period of 3 years displays a similar result with this study. The researchers have selected debt-to-equity ratio as one of the factors in capital structure in firms and use ROA as an indicator to measure the firms' performance. This research is conducted by Rouf and Abdur (2015) who stated that debt-to-equity ratio has a negative relationship with the ROA whereas increase in ROA will affect the value of debt-to-equity to decrease slightly.

Since the computed $p$-value of debt-to-equity ratio is greater than 0.05 , the null hypothesis which stated that debt-to-equity ratio experiences an insignificant relationship with ROA will be accepted. Thus, the results have concluded that there is a negative and insignificant relationship between debt-to-equity ratio and ROA in this study.

Since the computed $p$-value of debt ratio and debt-to-equity ratio is larger than 0.05 , it means that the null hypothesis of this study will not be rejected. We accepted the null 
hypothesis that the independent variables showed no significant relationship with dependent variable. This showed that although there is a positive relationship of debt ratio to ROA and negative relationship of debt-to-equity ratio to ROA, but the relationship is not significant at $5 \%$ significance level.

Ahmeti and Prenaj (2015) who stated that the second version of M\&M theory mentioned that increase in the debt-to-equity ratio will result in the higher cost of equity and it will cause a firm to default easier. Thus, the result in this study is supported by this theory whereas increase in debt-to-equity ratio will affect the value of ROA to decrease as firms face with high risk in financial planning when cost of equity is high. Besides, this result is also consistent with the Pecking Order Theory which stated that equity financing that required high cost of asymmetric information has become one of the main factors of excessive debt in firms (Jalal, 2007). Thus, when the amount of the funds needed for equity financing is too high, it will decrease the firms' value as the debt is too high.

The summary of the study is explained in the table below.

\begin{tabular}{|l|l|l|l|}
\hline \multicolumn{2}{|c|}{ Hypothesis } & \multicolumn{1}{|c|}{ Result } & \multicolumn{1}{c|}{ Conclusion } \\
\hline 1 & $\begin{array}{l}\mathrm{H}_{0} \text { : There is no significant relationship } \\
\text { between debt ratio and ROA of firms. } \\
\mathrm{H}_{1}: \text { There is significant relationship } \\
\text { between debt ratio and ROA of firms. }\end{array}$ & $\begin{array}{l}\text { The computed } \mathrm{p}- \\
\text { value is larger than } \\
0.05 .\end{array}$ & $\begin{array}{l}\text { Accept null } \\
\text { hypothesis, positive } \\
\text { and insignificant. }\end{array}$ \\
\hline 2 & $\begin{array}{l}\mathrm{H}_{0}: \text { There is no significant relationship } \\
\text { between debt to equity ratio and ROA } \\
\text { of firms. } \\
\mathrm{H}_{1}: \text { There is significant relationship } \\
\text { between debt to equity ratio and ROA } \\
\text { of firms. }\end{array}$ & $\begin{array}{l}\text { The computed } \mathrm{p}- \\
\text { value is larger than } \\
0.05 .\end{array}$ & $\begin{array}{l}\text { Accept null } \\
\text { hypothesis negative } \\
\text { and insignificant }\end{array}$ \\
\hline
\end{tabular}

As a conclusion, the major findings of this study showed that debt ratio experiences the positive relationship with ROA while debt to equity ratio shows the negative relationship with ROA. However, both the independent variables show the insignificant relationship with ROA. The result showed that increase in debt ratio will affect the value of ROA to increase while increase in debt to equity ratio will cause ROA to decrease. Higher value of ROA indicates that firms can use it assets well to create more profit. The overall results concluded that debt ratio and debt to equity ratio are not significantly affect to the value of ROA in consumer services listed firms from 2015 to 2019.

\section{Limitations of the study}

A number of limitations have been encountered during the course of this study. Firstly, this study only focuses on the consumer services listed firms in the main market of Bursa Malaysia. Other sectors such as finance, technology and manufacturing are not included in this study and hence, providing a less comprehensive results.

Secondly, the data analysed in this study only covers five years of observation period. This is because, some of the data are unavailable, incomplete and unattainable for data collection purposes. As a result, the outcome of this study does not fully represent the situation of consumer service firms in Malaysia. 
Thirdly, this study only examined consumer service firms that are listed in Bursa Malaysia. Consumer service firms from other countries around the globe are not included in this study, and hence, providing a less thorough result on the effect of debt and debt to equity ratio on ROA of firms. Other than that, only two independent variables are used in this study and therefore, resulting in a less comprehensive outcome.

\section{Recommendations for Future Study}

Firstly, recommendations for future study suggests to include more sectors that are registered in the field of finance, manufacturing and technology. This will increase the accuracy of the data and thus provides a clearer and comprehensive result. Results generated from different sectors can be analysed to examine the effect of financial crisis on firms. This will improve the overall results of the study in order to come up with a more significant and comprehensive outcome.

Secondly, future research is recommended to extend the observation period used in the study. When a longer period is used in the study, it will enhance the findings as well as the accuracy of the data. Therefore, a period of more than 5 years is more preferable to be analysed in the study to achieve a more accurate result. Longer period of data can benefit this study as it can significantly measure the performance of firms with different level of debt throughout the period observed.

Thirdly, it is suggested to include foreign companies for future study in analyzing the effect of debt and debt to equity ratio on the firms' performance. This can increase the attention of the readers of the report as it will be more interesting to evaluate firms from different countries. Different countries have different ways and skills in managing their debt management practices in order to maximize their profit. Thus, it is suggested to include foreign firms in the study to examine the overall impact of debt to the firms' performance. Besides, future study can also include more variables to provide a more in depth result such as interest coverage ratio and debt service coverage ratio to increase the level of accuracy of the result.

\section{References}

Ahmeti, F., \& Prenaj, B. (2015). A critical review of Modigliani and Miller's theorem of capital structure. International Journal of Economics, Commerce, and Management (IJECM), 3(6).

Al-Shubiri, F. N. (2012). Debt ratio analysis and firm investment: Evidence from Jordan. International Journal of Economics and Financial Issues, 2(1), 21.

Ali, A. (2020). Debt-to-equity ratio (9 October 2020), https://accountingsimplified.com/financial/ratio-analysis/debt-to-equity/

Bloomenthal, A. (2021). How do you calculate the debt-to-equity ratio (20 May 2021), Investopedia, https://www.investopedia.com/ask/answers/062714/what-formulacalculating-debttoequity-ratio.asp

Borad, S. B. (2021). Enterprise value (22 March 2021), Finance Management, https://efinancemanagement.com/financial-analysis/enterprise-value

Bragg, B. (2021). Debt ratios (6 September 2021), Accounting Tools, https://www.accountingtools.com/articles/debt-ratios.html

Bruer, W., \& Gurtler, M. (2008). 50 years after MM: recent developments in corporate finance. Journal of Business Economics 6. 
Charles. (2021). Breusch-Godfrey Test. Real Statistics Using Excel. Retrieved from https://www.real-statistics.com/multiple-regression/autocorrelation/breuschgodfrey-test/

Chen, J. (2020). Modigliani-Miller Theorem (25 April 2020), Investopedia, https://www.investopedia.com/terms/m/modigliani-millertheorem.asp

Chen, J. J. (2004). Determinants of capital structure of Chinese listed companies. Journal of Business Research, 57(12), 1341-1351.

Fernando, J. (2021). Debt-to-equtiy ratio (8 April 2021), Investopedia, https://www.investopedia.com/terms/d/debtequityratio.asp

Grunert, J. (2021). Debt-to-equity ratio (D/E) (8 February 2021), Investing Answers, https://investinganswers.com/dictionary/d/debt-equity-ratio

Hannagan, T. (2008). ROE vs ROA (5 December 2008), Experian, https://www.experian.com/blogs/insights/2008/12/roe-vs-roa/

Hargrave, M. (2021). Return on assets-ROA (8 April 2021), Investopedia, https://www.investopedia.com/terms/r/returnonassets.asp

Hayes, A. (2021). Debt ratio definition (20 September 2021), Investopedia, https://www.investopedia.com/terms/d/debtratio.asp

Hidayah, N. (2014). The effect of company characteristic toward company value in the property and real estate company in Indonesia Stock Exchange. International Journal of Business, Economics, and Law, 5(1), 1-8.

Karaca, S. S., \& Savsar, A. (2012). The effect of financial ratios on the firm value:

Evidence from Turkey. Journal of Applied Economic Sciences, 7(1), 56-63. Kenton, W. (2021). Financial crisis (23 April 2021), Investopedia, https://www.investopedia.com/terms/f/financial-crisis.asp

Lin, F. L., \& Chang, T. (2011). Does debt affect firm value in Taiwan? A panel threshold regression analysis. Applied Economics, 43(1), 117-128.

Mcclure, B. (2021). How to use ROA to judge a company's financial performance (27 July 2021), Investopedia, https://www.investopedia.com/articles/fundamental/04/012804.asp

Nachane, D. M. (2006). Econometrics: Theoretical foundations and empirical perspectives. OUP Catalogue.

Ross, S. (2021). What is a good debt ratio? (22 May 2021), Investopedia, https://www.investopedia.com/ask/answers/021215/what-good-debt-ratio-andwhat- bad-debt-ratio.asp

Rouf, D., \& Abdur, M. (2015). Capital structure and firm performance of listed non-financial companies in Bangladesh. The International Journal of Applied Economics and Finance, 9(1), 25-32

Stephanie. (2016). What is the Jarque-Bera Test? Statistics How To. Retrieved from https://www.statisticshowto.com/jarque-bera-test/

Tracy, P. (2021). What is enterprise value (EV)? (June 30 2021), Investing Answers, https://investinganswers.com/dictionary/e/enterprise-value

Tuovila, A. (2021). Capital structure (4 September 2021), Investopedia, https://www.investopedia.com/terms/c/capitalstructure.asp 